\title{
Race Talk: Jameela, Justice, Jihad
}

\section{James (Jimmy) Jones*}

As a "Black" man in America ...The terror is real ... The pain is palpable ... The trauma is deep ...

On May 25, 2020, George Floyd was killed while in the custody of Minneapolis police officers. The video of his demise under the knee of a 20 -year police veteran who was also a "field training officer" went viral and resurfaced this country's deadly history of racial violence at the hands of sworn "peace" officers. The 8 minutes and 46 seconds that the officer kneeled on Floyd's neck literally rocked the world with multi-cultural and multi-national protests for weeks. Some of them remain ongoing.

Sadly, there were no such protests or outrage when Jameela Yasmeen Arshad died on January 10, 2005, while in the custody of Kenner's (LA) police. Her story is as all-American as it can get. An immigrant who had come to the US after high school, she eventually attained a pre-med degree from Lehman College, City University of New York. After graduating from the George Washington School of Medicine, she ultimately became a successful, well-respected medical doctor whose specialties included neurology, internal medicine, emergency medicine, and pain management. On the evening of January 10, 2005, she did what any good Muslim or conscientious medical doctor would do - she stopped to assist a child who had been hit by a vehicle. What happened immediately afterward is a matter of dispute (without Dr. Arshad being alive to give her version).

However, what is clear from a reading of official court transcripts is that none of the police on the scene believed that this middle-aged "Black" woman could possibly be a doctor. Since she could not produce her credentials right away, the situation escalated to such a point that an officer used a "leg sweep" to bring her face down on the ground, sat on her while he handcuffed her, and ended with her dying in the back of a police vehicle. Despite the terror, pain, and trauma caused by countless situations like the two above, our understandable outrage should not cause us to lose our morals and our minds.

O ye who believe, stand out firmly for Allah, as witnesses to fair-dealing, and let not the hatred of others to you make you serve to wrong and depart from justice. Be just! That is next to piety; and fear Allah, for Allah is well-acquainted with all that you do. (5:8)

\footnotetext{
* James (Jimmy) Jones is Professor emeritus of African Studies and World Religions at Manhattanville College and Executive Vice President and Professor at The Islamic Seminary of America.
} 
The Quran and life-example of the Prophet Muhammad (PBUH) are clear Islam's moral code forbids us to be unjust even if others are unjust to us. Consequently, we cede Islam's moral high ground when we participate in racist namecalling or angry acts of violence against persons or property simply because we are mad. A riot is a riot, no matter who precipitates it or participates in it. No amount of verbal word play by college professors or media pundits can obscure this fact.

Five years after the riots following the police custody killing of Freddie Gray, my hometown of Baltimore has yet to recover. Hundreds of structures in the "Black" community are still fire-damaged, and we have a primarily black-onblack murder rate of about 300 people per year. Additionally, when we look at the history of racial riots in this country, the deadliest ones that resulted in the loss of life were clearly those done by "Whites" against "Blacks." For example, the infamous Tulsa (OK) race riot of 1921 destroyed more than 35 square blocks of what was known at that time as Black Wall Street, left approximately 800 wounded, and left more than 30 members of the "Black" community dead.

"The best thing that we can learn to do is to think for ourselves."

- Malcolm X

This oft-quoted phrase attributed to Malcolm X reminds us that should not let our righteous anger at police-involved shootings cloud our intellect. For instance, we defy logic when we:

1. Claim that "Black-on-Black" violence should not be a part of the discussion of police-involved shootings. One of the main reasons that inner-city neighborhoods (like the one in which I live) are policed like a war zone is because of the easy access to guns (thanks to the NRA and others). These issues are clearly related.

2. Label ourselves "Black" Muslims, as if the term describes an essentially homogenous group. Any cursory examination of who we are reveals a community that is much more diverse than it was 60 years ago (see Chapter 1 of Eugene Robinson's Disintegration: The Splintering of Black America for an insightful discussion of this based on facts - census data - rather than angry feelings and simplistic rhetoric). We should not primarily define ourselves based on our collective victimization.

3. Act as if there is more than one race - the human race. The fact that all human beings have common ancestors is something that the Quran (see 4:1) and even staunch atheistic Darwinists like the biologist Richard Dawkins agree upon! 
If we are to be witnesses for all humanity (2:143) and play a decisive role in leading the nation and the world out of this and other current crises, we must regain our Islamic morals and intellect.

So, when it comes to racism and other oppressions, the most important jihad for those of us who reside in the United States of America is not a physical fight. Rather, it is the more intense jihā dal-nafs - that is, the struggle against those individual weak internal inclinations that call us to "fight fire with fire." We cannot be students of the meanest part of ourselves, and thus we should struggle daily to emulate our beloved Prophet (PBUH), who was sent as a mercy to all of creation. 